\title{
Evaluation of Friction-Slit Hybrid Dampers in Moment - Resisting Steel Frames
}

\author{
Azadeh Khoshkroodi ${ }^{1}$ and Hossein Parvini Sani ${ }^{2}$ \\ ${ }^{1}$ M.Sc. Graduate, Structural Engineering, Department of Civil Engineering, College of Engineering, \\ Zanjan Branch, Islamic Azad University, Zanjan, Iran \\ ${ }^{2}$ Assistant Professor, Structural Engineering, Department of Civil Engineering, College of \\ Engineering, Zanjan Branch, Islamic Azad University, Zanjan, Iran
}

\begin{abstract}
This paper investigates the friction-slit hybrid dampers with two different behaviors in the moment- resisting steel frames. For this purpose, 5, 10 and 15 stories, models of steel construction frames have been considered, and the mentioned also dampers have been added as a brace. These structural models were subjected to nonlinear static analyzes (pushover) and nonlinear dynamic analysis (time history) using seven pairs of far-field records. Nonlinear behavior and response in the analysis were also considered by applying nonlinear characteristics for the dampers in the frame and by assigning plastic hinges to structural members. Therefore, the probability of failure decreases. Based on the numerical results, adding this damper to the frame, reduces drift by $33 \%$ the maximum displacement of the roof by $23 \%$ in pushover analysis, and reduces displacement, velocity and acceleration by $60 \%, 70 \%$ and $45 \%$, and ultimately reduces the kinetic energy by $51 \%$ in time history analysis.
\end{abstract}

Keywords: Earthquake, Seismic Analysis, Nonlinear analysis, Damper, Steel Frame, Displacement, Plastic Hinges.

\section{INTRODUCTION}

Recently, two of the most abundant energy dissipation devices used in building structures are friction and metallic fluid dampers. Energy dissipation devices have various shapes, such as ADAS [1], adding damping and adding stiffness, resistant buckling braces [2] and slit dampers [3]. Among the metal dampers, the slit steel plate dampers are advantage to the other dampers, due to their easy design and construction [4-8]. Friction dampers used in various forms have been used by [9], and [10]. Recently, [11] expanded friction dampers by friction created between low-alloyed materials and softened steel. Energy dissipation devices and inactive dampers are used to greatly enhance seismic of structures. Some researchers also investigate the simultaneous use of these tools to increase energy dissipation capacity. For example, [12-14] studied hybrid tools. These devices are displacementdependent and velocity-dependent to reduce seismic of structures and minimize the faults of the dampers which are used individually. [15] studied the effect of hybrid friction-viscoelastic dampers with the placement of these dampers between the shear wall and showed that the seismic responses of the structures, when these dampers are placed in the structure.[16] studied hybrid systems, which were composed of resistant buckling braces and viscous fluid tools, and investigated the seismic responses of structures. They also studied the optimal design methods for composite dampers that were made up of a combination of resistant buckling braces and viscous fluid tools, and investigated the seismic responses of structures. Optimal design methods for hybrid or multiple dampers were developed by [17-18]. They investigated the effect of these hybrid tools, consisting of slit and friction dampers, in reducing the seismicity of structures in small and large earthquakes. [19] investigated the hybrid effect of shear-type friction dampers and slit dampers with non-uniform tapes in seismic protection for different levels of energy.[20] studied combined dampers consisting of friction and split dampers in response to small and large earthquakes. Previous results have shown the ability of inactive hybrid systems to improve the reaction of structures to conventional systems. The purpose of this study is to investigate the behavior of hybrid dampers in steel structures. For this purpose, the behavior of the moment resisting steel frames of the structures in the original state and equipped with a hybrid damper, with two different behaviors is analyzed and investigated. In addition to the nonlinear behavior due to the presence of dampers, in both cases, the nonlinear behavior of frame members can also occur through the assignment of plastic hinges to see more realistic behavior of the models. 
International Journal of Advances in Scientific Research and Engineering (ijasre), Vol 5 (5), May-2019

\section{SLIT- FRICTION HYBRID DAMPER}

The hybrid dampers are formed from a combination of friction and split dampers. The steel plate of slit dampers consists of a large number of strips, where these strips with the same sizes has been shown in Figure 1. Stiffness and yielding strength of plate strips can be obtained according to the following equations 1 and 2 [20]:

$$
\begin{aligned}
& K_{s}=\mathrm{n} \frac{12 \mathrm{EI}}{l_{0}{ }^{3}}=\mathrm{n} \frac{\mathrm{Etb}^{3}}{l_{0}{ }^{3}} \\
& P_{y s}=\frac{2 n M_{p}}{l_{0}}=\frac{n \sigma_{y} t b^{2}}{2 l_{0}}=\frac{n \sigma_{y} t b^{2}}{2 l_{0}}
\end{aligned}
$$

Where " $n$ " is the number of stripes, "t" is the thickness of the strips, "b" is the width of the strips and "lo" is equal to the vertical length of the strips. The friction damper starts its function when the applied load comes to the sliding force. The initial stiffness of the rotational friction dampers is very large, and its yielding strength is obtained according to the following equation 3 [20] :

$$
P_{\mathrm{yf}}=2 \mu \mathrm{NQ} \frac{\mathrm{R}_{\mathrm{m}}}{\mathrm{L}_{0}}
$$

According to the equation 3, " $\mathrm{L}_{0}$ "is the length between two stripe plates, " $\mu$ " is the coefficient of friction of the plate, "N" is the number of friction surfaces, "Q" is the clamping force, " $\mathrm{R}_{\mathrm{m}}$ " is the effective area of the friction surface. Friction and split dampers are connected in parallel. In this case, the initial stiffness and yielding strength of hybrid damper is obtained according to experimental results, that display in table.1. In this paper, the hybrid damper behavior includes type of Rubber Isolator element and the Plastic Wen element, which is modeled by ETABS, 2016 software [21]. These dampers have been added as a brace in moment- resisting steel frames, the joints of the upper and lower plates of the dampers to the beam and brace can be in the form of screws or welded joints that screws joints have the advantage of more easily replacing the device after severe earthquakes.

(a)

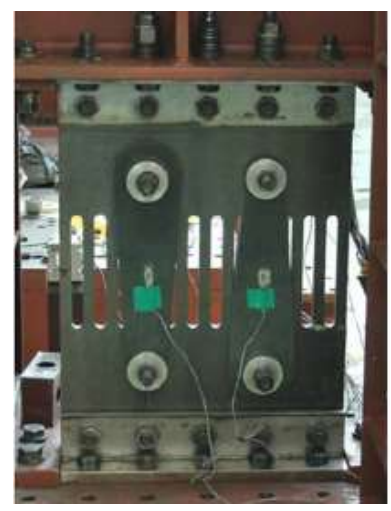

(b)

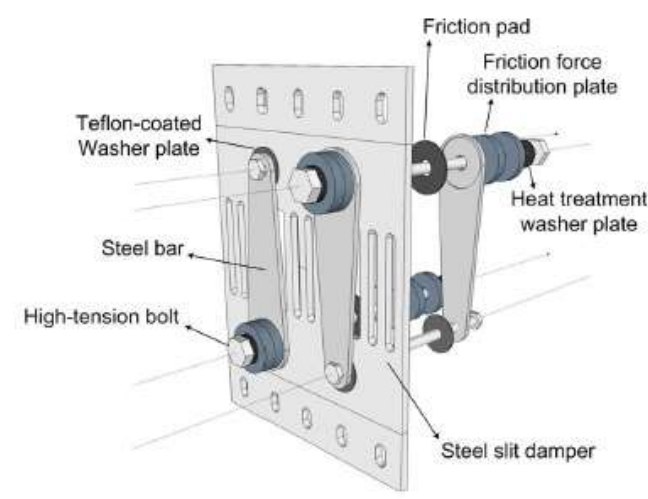

(c)

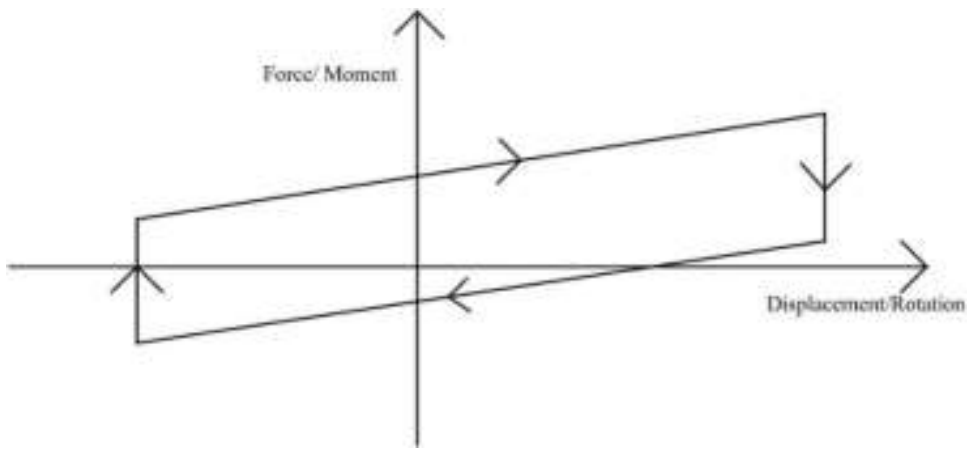

Figure 1. The SFHD in laboratory: (a) Hybrid Damper; (b) Schematic picture of the SFHD; (c) Bilinear curve [20]. 
International Journal of Advances in Scientific Research and Engineering (ijasre), Vol 5 (5), May-2019

\section{MODELING AND ANALYSIS ASSUMPTIONS}

Structural models used in this research are considered as moment -resisting steel frames, with moderate ductility. The number of stories are 5, 10 and 15, each of them has 5 bays of $5 \mathrm{~m}$, in X direction and 3 bays of $5 \mathrm{~m}$, in $\mathrm{Y}$ direction, and the dampers are placed between the upper ends of the braces and the lower part of the beam in the frames. The height of the first story is $4 \mathrm{~m}$ and the other stories are $3.6 \mathrm{~m}$, and it is assumed that the connection are fixed connection. The sections used for columns and braces are BOX and for IPE beams, are shown in Tables $(2,3,4)$, the geometry of the frames used together with the sections of its members is shown in Figure 2. Amount of the dead load, live load, live load of the roof, snow load and partition load are $600 \mathrm{~kg} / \mathrm{m}^{\wedge} 2,240 \mathrm{~kg} / \mathrm{m}^{\wedge} 2,96 \mathrm{~kg} / \mathrm{m}^{\wedge} 2,196 \mathrm{~kg} / \mathrm{m}^{\wedge} 2$ and $126 \mathrm{~kg} / \mathrm{m}^{\wedge} 2$ in the design of frames, respectively. Seismic loading for initial analysis and design is based on the ASCE07, 2016 code [22]. The loading bearing of the roof steel decking type. Critical damping ratio in the structure is $5 \%$, soil is of D type, construction site is in Montana State. In structures with hybrid dampers, cause to the frame members remains in the form of elasticity and only the damper enters into the nonlinear zone. After initial design of the frames with mentioned loading, a nonlinear static analysis (pushover) and nonlinear time analysis (time history) was performed by software ETABS2016 to study the behavior of frames without damper and equipped with a damper during an earthquake. For this purpose use seven pairs of far-filed were used according to the FEMA-P695, 2009 [23], which has been shown in Table 5. In nonlinear static analysis, two combinations of 1.1DL + 0.75LL and 0.9DL loads have been used in both $\mathrm{X}$ and $\mathrm{Y}$ directions, and nonlinear time histories analysis is considered as a direct integration. Damping of the structure (other than the adjunct damper) has been considered as in a damping proportional to mass and stiffness (Riley assumption) with damping ratio of $5 \%$.

(a)

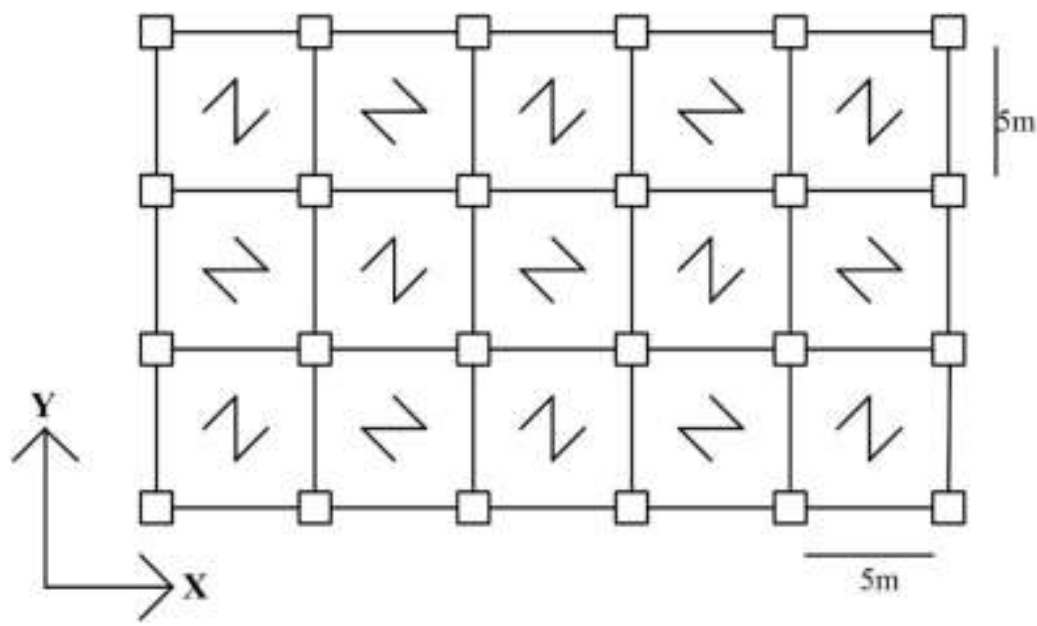

(b)

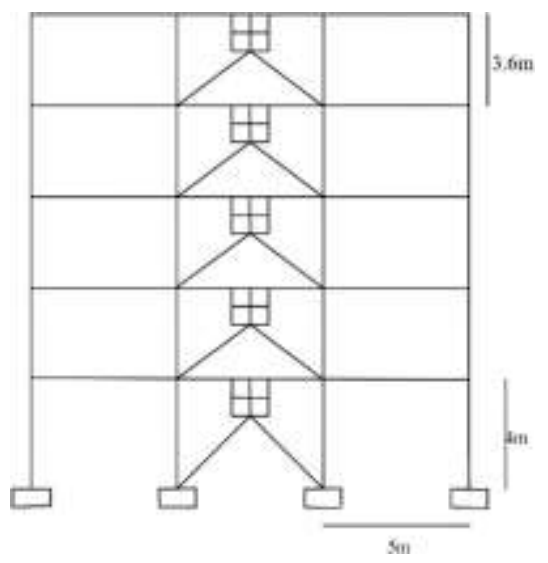

(c) 
International Journal of Advances in Scientific Research and Engineering (ijasre), Vol 5 (5), May-2019

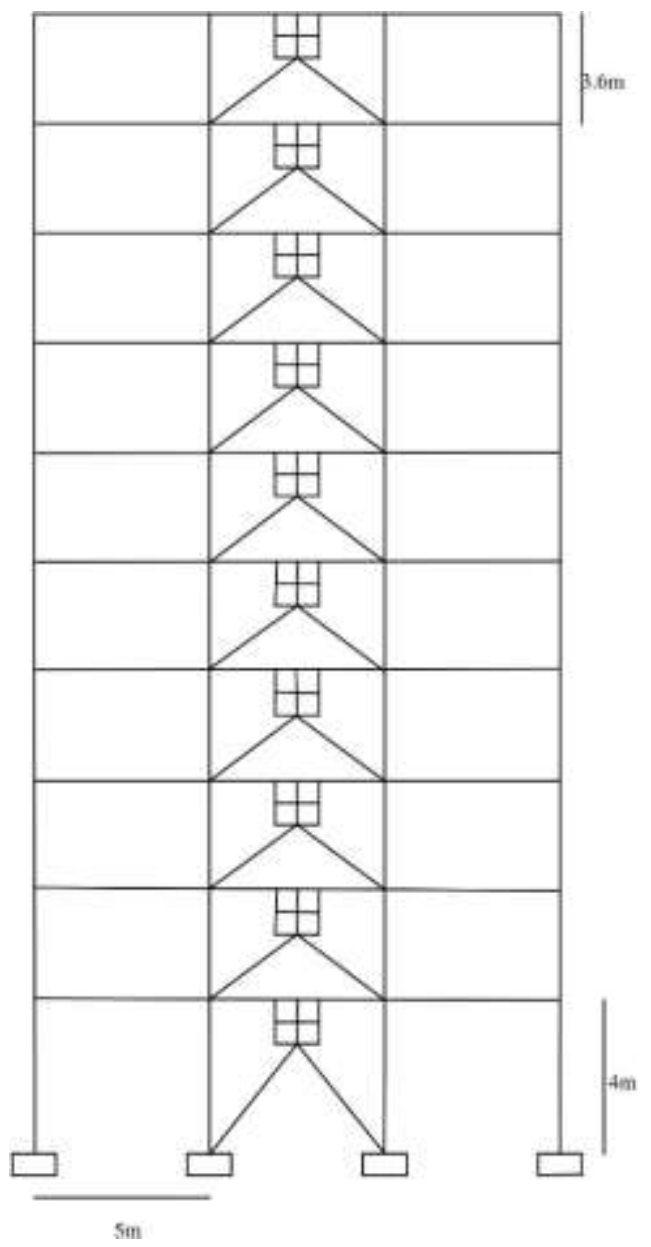

(d) 
International Journal of Advances in Scientific Research and Engineering (ijasre), Vol 5 (5), May-2019

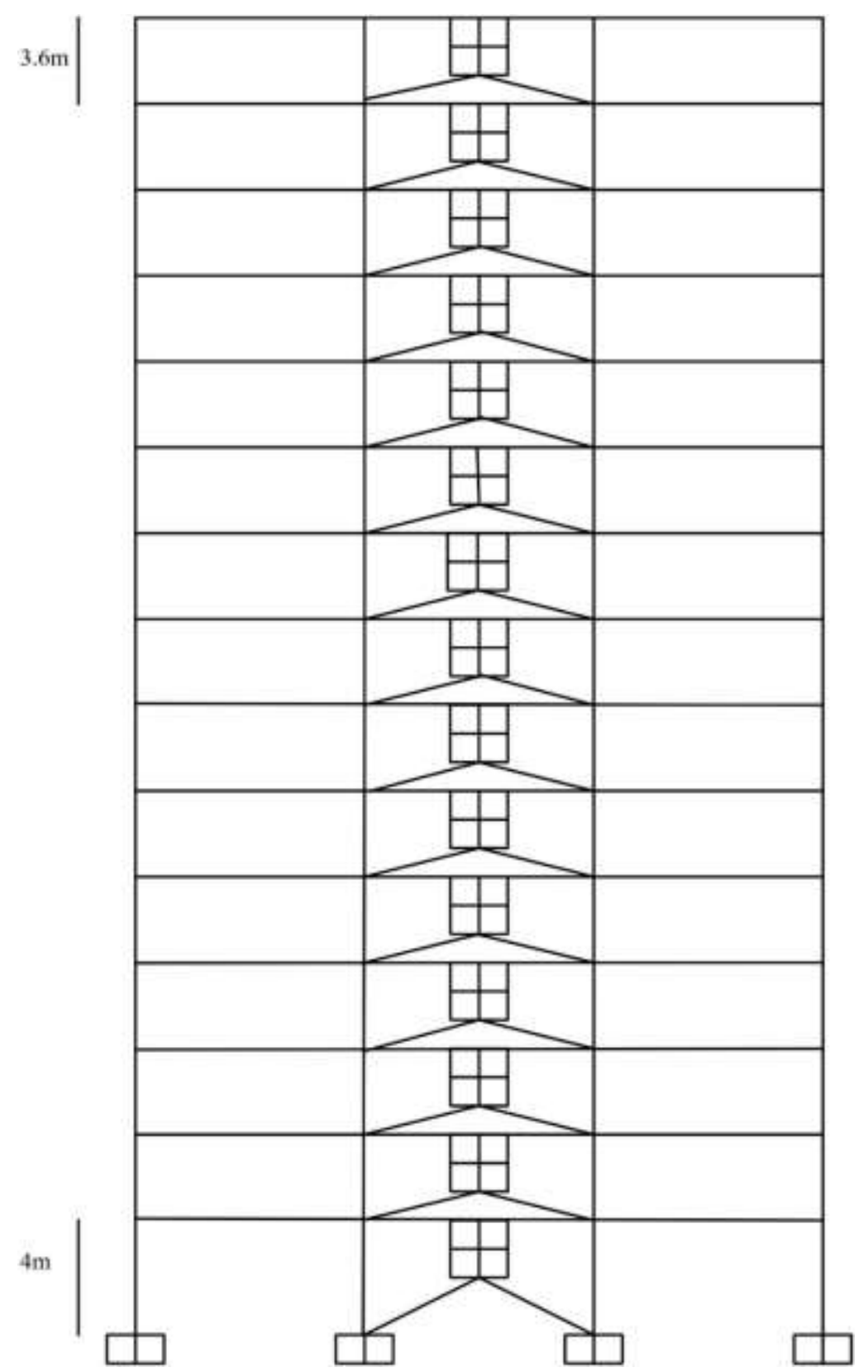

Figure 2. Schematic Geometry of the used frames: (a) Plan of the structure; (b) Elevation of 5 stories stucture; (c) Elevation of 10 stories structure; (d) Elevation of 15 stories structure

Table 1 Properties of the friction damper, the slit damper and the hybrid damper from experiments and analytical models [20].

\begin{tabular}{lll}
\hline & Theoretical values & Experimental results \\
\hline$\left(\delta_{y \text { friction }}, P_{y \text { friction }}\right)$ & $(0 \mathrm{~mm}, 37.5 \mathrm{kN})$ & $(0.8 \mathrm{~mm}, 37.8 \mathrm{kN})$ \\
$\left(\delta_{y \text { slit }}, P_{y \text { slit }}\right)$ & $(1.6 \mathrm{~mm}, 48.75 \mathrm{KN})$ & $(3.0 \mathrm{~mm}, 46.7 \mathrm{Kn})$ \\
$\left(\delta_{\max }, P_{\max }\right)$ & $(65.0 \mathrm{~mm}, 124.8 \mathrm{KN})$ & $(63.38 \mathrm{~mm}, 120.0 \mathrm{Kn})$ \\
$K_{S E}$, Elastic stiffness of slit dampers & $30.66 \mathrm{Kn} / \mathrm{mm}$ & $15.57 \mathrm{kN} / \mathrm{mm}$ \\
$K_{S p}$, Post-yield stiffness of slit dampers & $0.61 \mathrm{kN} / \mathrm{mm}$ & $0.60 \mathrm{KN} / \mathrm{mm}$ \\
\hline
\end{tabular}


International Journal of Advances in Scientific Research and Engineering (ijasre), Vol 5 (5), May-2019

Table 2. Section size of the 5 stories model structure.

\begin{tabular}{llll}
\hline \multicolumn{1}{c}{ Applied sections } & & \\
Number of the stories & Columns & Beams & Braces \\
\hline First story & BOX:250*250*20 & IPE330 & BOX:120*120*10 \\
Second story & $B O X: 250 * 250 * 20$ & IPE330 & BOX: $120 * 120 * 10$ \\
Third story & BOX:200*200*20 & IPE300 & BOX:120*120*10 \\
Fourth story & BOX:200*200*20 & IPE300 & BOX: $120 * 120 * 10$ \\
Fifth story & BOX:180*180*20 & IPE240 & BOX:120*120*10 \\
\hline
\end{tabular}

Table 3. Section size of the 10 stories model structure.

\begin{tabular}{|c|c|c|c|}
\hline \multicolumn{4}{|l|}{ Applied sections } \\
\hline Number of the stories & Columns & Beams & Braces \\
\hline First story & $B O X: 350 * 350 * 20$ & IPE360 & BOX: $180 * 180 * 10$ \\
\hline Second story & $B O X: 350 * 350 * 20$ & IPE360 & BOX: $180 * 180 * 10$ \\
\hline Third story & BOX: $350 * 350 * 20$ & IPE360 & BOX: $180 * 180 * 10$ \\
\hline Fourth story & BOX: $350 * 350 * 20$ & IPE360 & BOX: $180 * 180 * 10$ \\
\hline Fifth story & BOX: $330 * 330 * 20$ & IPE330 & BOX: $180 * 180 * 10$ \\
\hline Sixth story & BOX: $330 * 330 * 20$ & IPE330 & BOX: $180 * 180 * 10$ \\
\hline Seventh story & BOX: $330 * 330 * 20$ & IPE300 & BOX: $180 * 180 * 10$ \\
\hline Eighth story & BOX: $330 * 330 * 20$ & IPE300 & BOX: $180 * 180 * 10$ \\
\hline Ninth story & $B O X: 300 * 300 * 20$ & IPE270 & BOX: $180 * 180 * 10$ \\
\hline Tenth story & BOX: $300 * 300 * 20$ & IPE270 & BOX: $180 * 180 * 10$ \\
\hline
\end{tabular}

Table 4. Section size of the 15 stories model structure.

\begin{tabular}{llll}
\hline $\begin{array}{l}\text { Applied sections } \\
\text { Number of the stories }\end{array}$ & Columns & Beams & Braces \\
\hline First story & $B O X: 450 * 450 * 25$ & $I P E 400$ & $B O X: 200 * 200 * 10$ \\
Second story & $B O X: 450 * 450 * 25$ & $I P E 400$ & $B O X: 200 * 200 * 10$ \\
Third story & $B O X: 450 * 450 * 25$ & $I P E 400$ & $B O X: 200 * 200 * 10$ \\
Fourth story & $B O X: 400 * 400 * 25$ & $I P E 360$ & $B O X: 200 * 200 * 10$ \\
Fifth story & $B O X: 400 * 400 * 25$ & $I P E 360$ & $B O X: 200 * 200 * 10$ \\
Sixth story & $B O X: 400 * 400 * 25$ & $I P E 360$ & $B O X: 180 * 180 * 10$ \\
Seventh story & $B O X: 350 * 350 * 20$ & $I P E 330$ & $B O X: 180 * 180 * 10$ \\
Eighth story & $B O X: 350 * 350 * 20$ & $I P E 330$ & $B O X: 180 * 180 * 10$ \\
Ninth story & $B O X: 350 * 350 * 20$ & $I P E 330$ & $B O X: 180 * 180 * 10$ \\
Tenth story & $B O X: 300 * 300 * 20$ & $I P E 300$ & $B O X: 180 * 180 * 10$ \\
Eleventh story & $B O X: 300 * 300 * 20$ & $I P E 300$ & $B O X: 160 * 160 * 10$ \\
Twelfth story & $B O X: 300 * 300 * 20$ & $I P E 300$ & $B O X: 160 * 160 * 10$ \\
Thirteenth story & $B O X: 250 * 250 * 15$ & $I P E 270$ & $B O X: 160 * 160 * 10$ \\
Fourteenth story & $B O X: 250 * 250 * 15$ & $I P E 270$ & $B O X: 160 * 160 * 10$ \\
Fifteenth story & $B O X: 250 * 250 * 15$ & $I P E 270$ & $B O X: 160 * 160 * 10$ \\
\hline
\end{tabular}


International Journal of Advances in Scientific Research and Engineering (ijasre), Vol 5 (5), May-2019

Table 5. seven pairs of far-field accelertion records [23]

\begin{tabular}{|c|c|c|c|c|c|c|}
\hline \multicolumn{7}{|c|}{ PEER-NGA Records Information } \\
\hline $\begin{array}{l}I D \\
\text { No. }\end{array}$ & $\begin{array}{l}\text { Record } \\
\text { Seq. No. }\end{array}$ & $\begin{array}{c}\text { Lowest } \\
\text { Freq }(H Z)\end{array}$ & Component 1 & Component 2 & $\begin{array}{c}P G A_{\max } \\
(\mathrm{g})\end{array}$ & $\begin{array}{c}P G V_{\max } \\
(\mathrm{cm} / \mathrm{s})\end{array}$ \\
\hline 1 & 169 & 0.06 & IMPVALL/H-DLT262 & IMPVALL/H-DLT352 & 0.35 & 33 \\
\hline 2 & 174 & 0.25 & IMPVALL/H-E11140 & IMPVALL/H-E11230 & 0.38 & 42 \\
\hline 3 & 752 & 0.13 & LOMAP/CAPOOO & LOMAP/CAP09O & 0.53 & 35 \\
\hline 4 & 767 & 0.13 & LOMAP/G03000 & LOMAP/G03090 & 0.56 & 45 \\
\hline 5 & 848 & 0.13 & $L A N D E R S / C L W-L N$ & LANDERS/CLW-TR & 0.42 & 42 \\
\hline 6 & 900 & 0.07 & LANDERS/CLW-YER270 & LANDERS/CLW-YER360 & 0.24 & 52 \\
\hline 7 & 953 & 0.25 & NORTHR/MULOO9 & NORTHR/MUL279 & 0.52 & 63 \\
\hline
\end{tabular}

\section{NUMERICAL RESULTS}

\section{4-1. Pushover analysis outcome}

The development of the nonlinear static analysis also called the pushover analysis, originated as simplified performance evaluation tool. Pushover analysis uses height-wise lateral load distribution pattern considering the contribution of higher modes as in the modal pushover analysis to calculate the inelastic seismic demands of the structure [24]. Static pushover analysis provides advantageous data on the lateral strength and ductility of structures [25].

\section{4-1-1. Drift}

In Figure 3, drift has been shown according pushover analysis in 5, 10 and 15 stories. According to this analysis, drift of structures equipped with hybrid damper with Rubber Isolator behavior is better than structures equipped with hybrid damper with Plastic Wen behavior and also performance of structures retrofitted with slit and friction dampers, mostly are similar together. The reduce of drift in structure equipped with hybrid damper with Rubber Isolator behavior is in 5 story 33\%, in 10 story $28 \%$ and in 15 story $37 \%$ in compered with original structures.

\section{4-1-2. Roof Displacement}

Figure 4, show the roof displacement in structures 5, 10, and 15 stories under pushover analysis, it can be seen that in structures equipped with a hybrid damper (with Rubber Isolator behavior ), the displacement of the roof has decreased in 5 story $20 \%$, in 10 story $16 \%$ and in 15 story $33 \%$ compared with the structure without a damper, and the performance of the structures equipped with a hybrid damper (with Rubber Isolator behavior) is so better than the structures equipped with friction, slit and hybrid (with plastic wen) due to the effective damping coefficient in the modeling of the hybrid damper (with Rubber Isolator behavior). Decrease in roof displacement reduces structural element and non-structural element damages and plastic rotations.

\section{TIME HISTORY ANALYSIS}

Nonlinear dynamic analyses were conducted on the 5,10 and 15 stories under 7 pairs of a far- filed ground motions.

\section{5-1. Displacement of the structure}

Figure 5, is shown the displacement of the structure under the Imperial Valley earthquake. According to the diagrams, the displacement of the structure in structures equipped with hybrid, friction and split dampers, with two types of the Rubber Isolator and plastic wen behavior, has decreased by $80 \%$ in 5 story, by $69 \%$ in 10 story and by $30 \%$ in 15 story, than original structures, it is observed that all dampers have the same function.

\section{5-2. Velocity of the structure}

Figure 6, shows the velocity of structure under the Imperial Valley earthquake. The velocity of structure, in structures equipped with hybrid, friction, and slit dampers with two types of the Rubber Isolator and Plastic Wen behavior has decreased by $75 \%$ in 5 story, by $63 \%$ in 10 story and by $70 \%$ in 15 story than the original structures, that is shows all dampers have the same function. 
International Journal of Advances in Scientific Research and Engineering (ijasre), Vol 5 (5), May-2019

\section{5-3. Acceleration of structure}

Figure 7 shows the acceleration of structure under the Imperial Valley earthquake the acceleration of structure in structures with hybrid, friction, and slit dampers with two types of the Rubber Isolator and Plastic Wen behavior has decreased by $33 \%$ in 5 story, by $57 \%$ in 10 story and by $46 \%$ in 15 story than the original structures, that is shows all dampers have the same function.

\section{5-4. Kinetic energy of structure}

Figure 8, shows the kinetic energy of structure under the Imperial Valley earthquake. According to the curves, the kinetic energy of structure in structures, equipped with hybrid, friction, and slit dampers with two types of the Rubber Isolator and plastic wen behavior has decreased by $51 \%$ in 5 story, by $42 \%$ in 10 story and by $62 \%$ in 15 story than the original structures, that it shows all hybrid dampers (with Rubber Isolator behavior) have better function than other dampers.
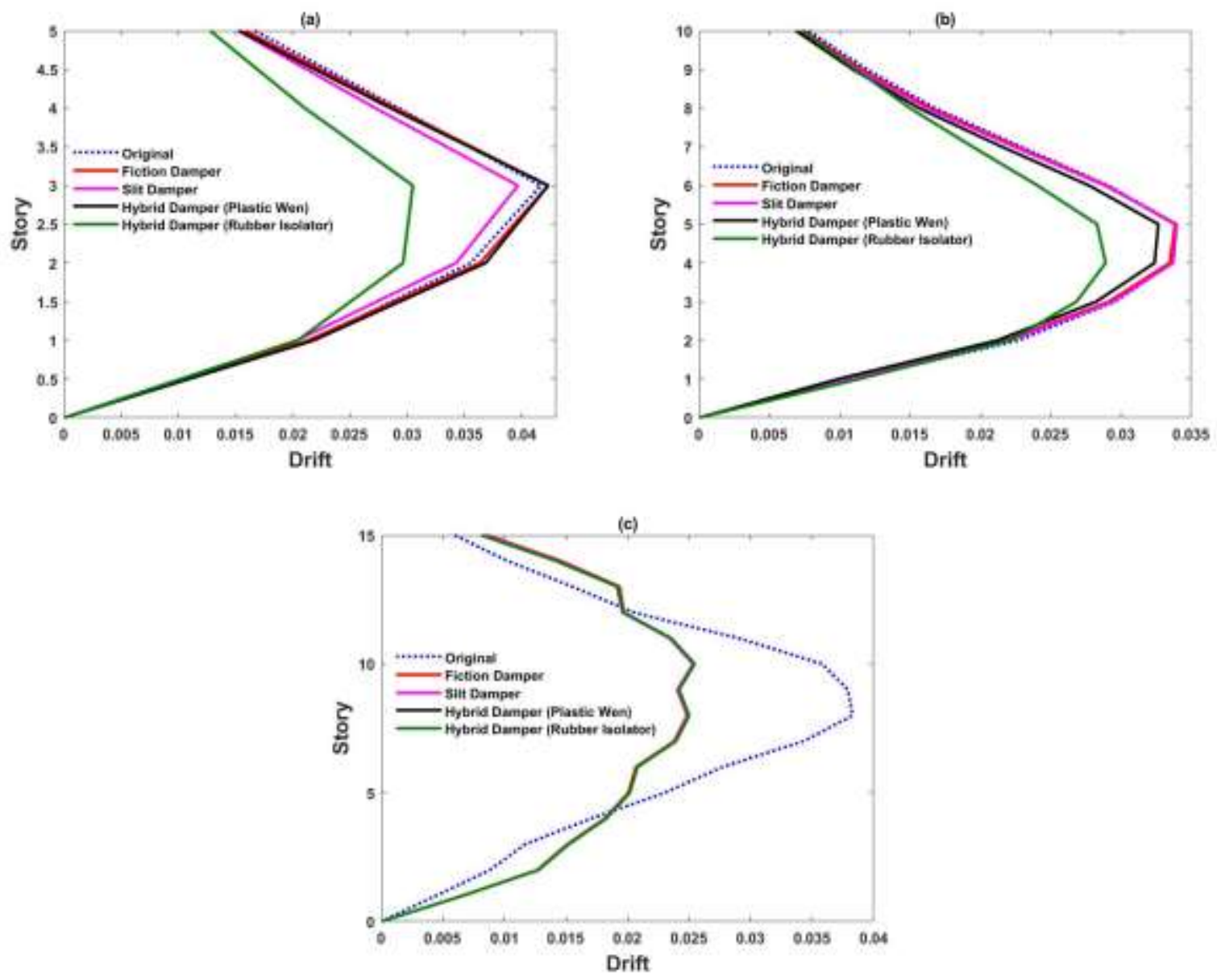

Figure 3. Drift: (a) the 5-story structure; (b) the 10-story structure; (c) the 15-story structure
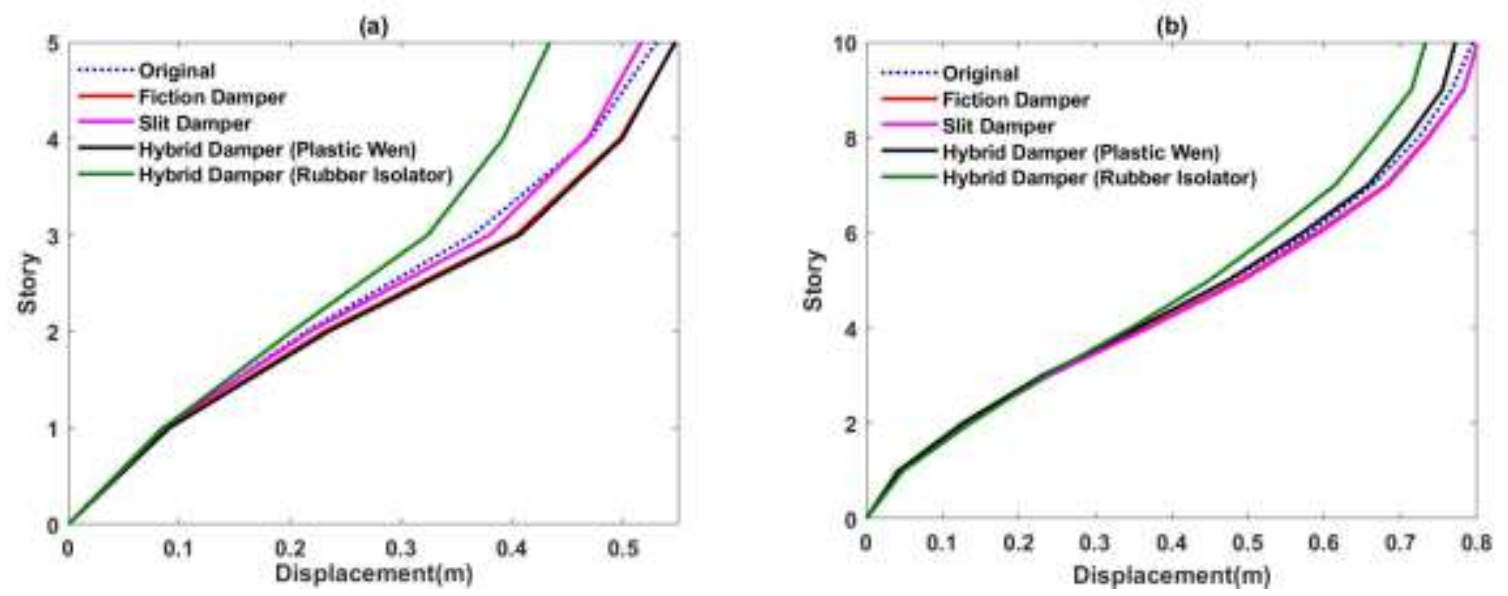
International Journal of Advances in Scientific Research and Engineering (ijasre), Vol 5 (5), May-2019

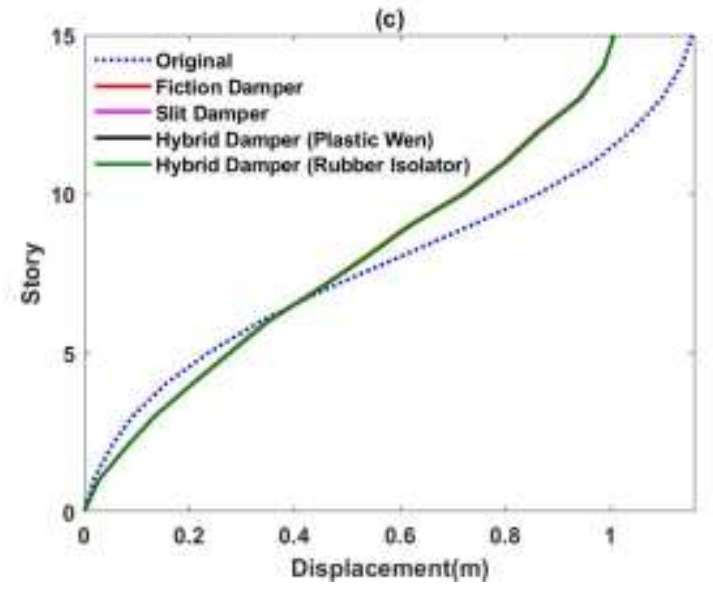

Figure 4. Displacement of roof: (a) the 5-story structure; (b) the 10-story structure; (c) the 15-story structure
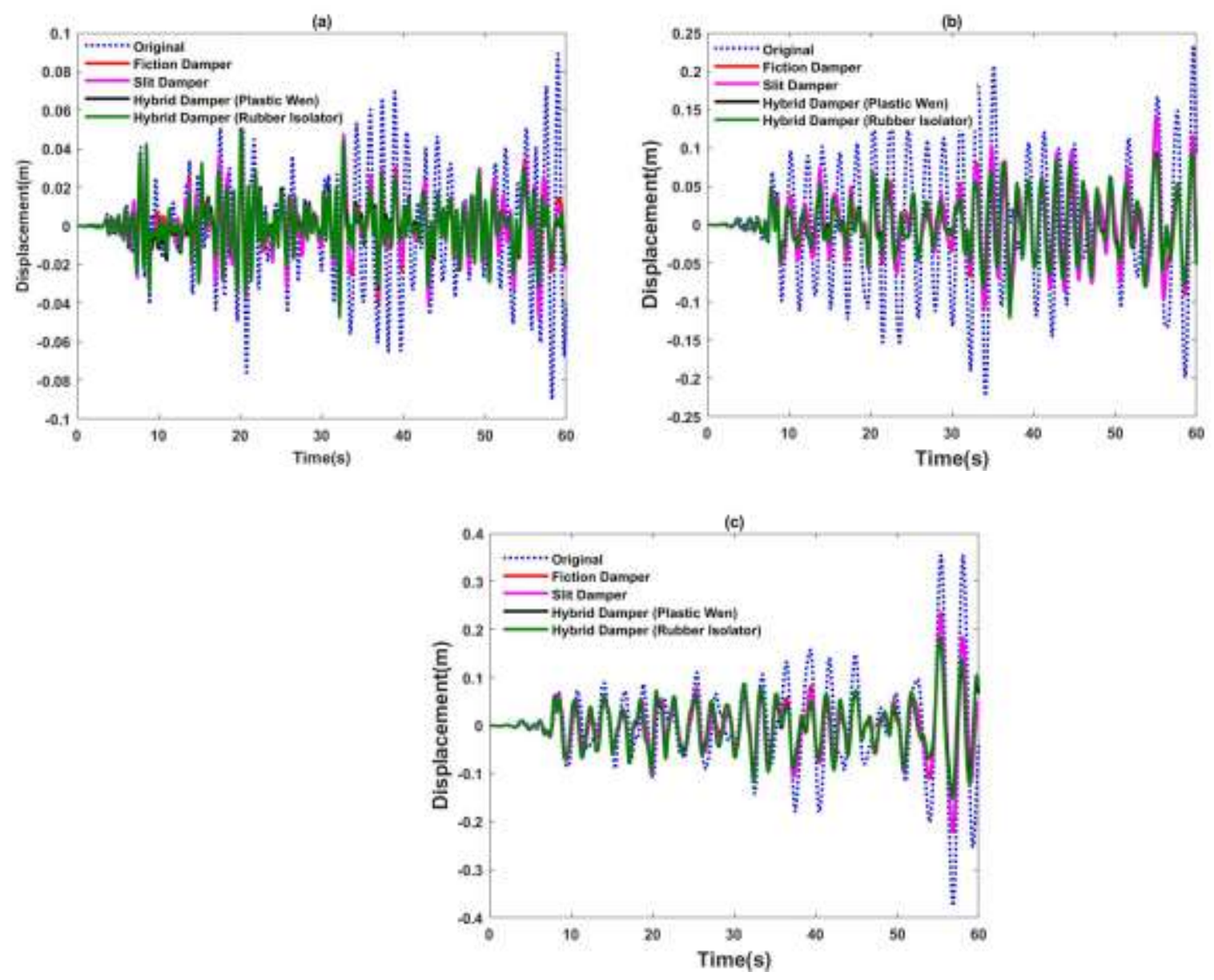

Figure 5. Displacement of the structure: (a) the 5-story structure; (b) the 10-story structure; (c) the 15-story structure 
International Journal of Advances in Scientific Research and Engineering (ijasre), Vol 5 (5), May-2019
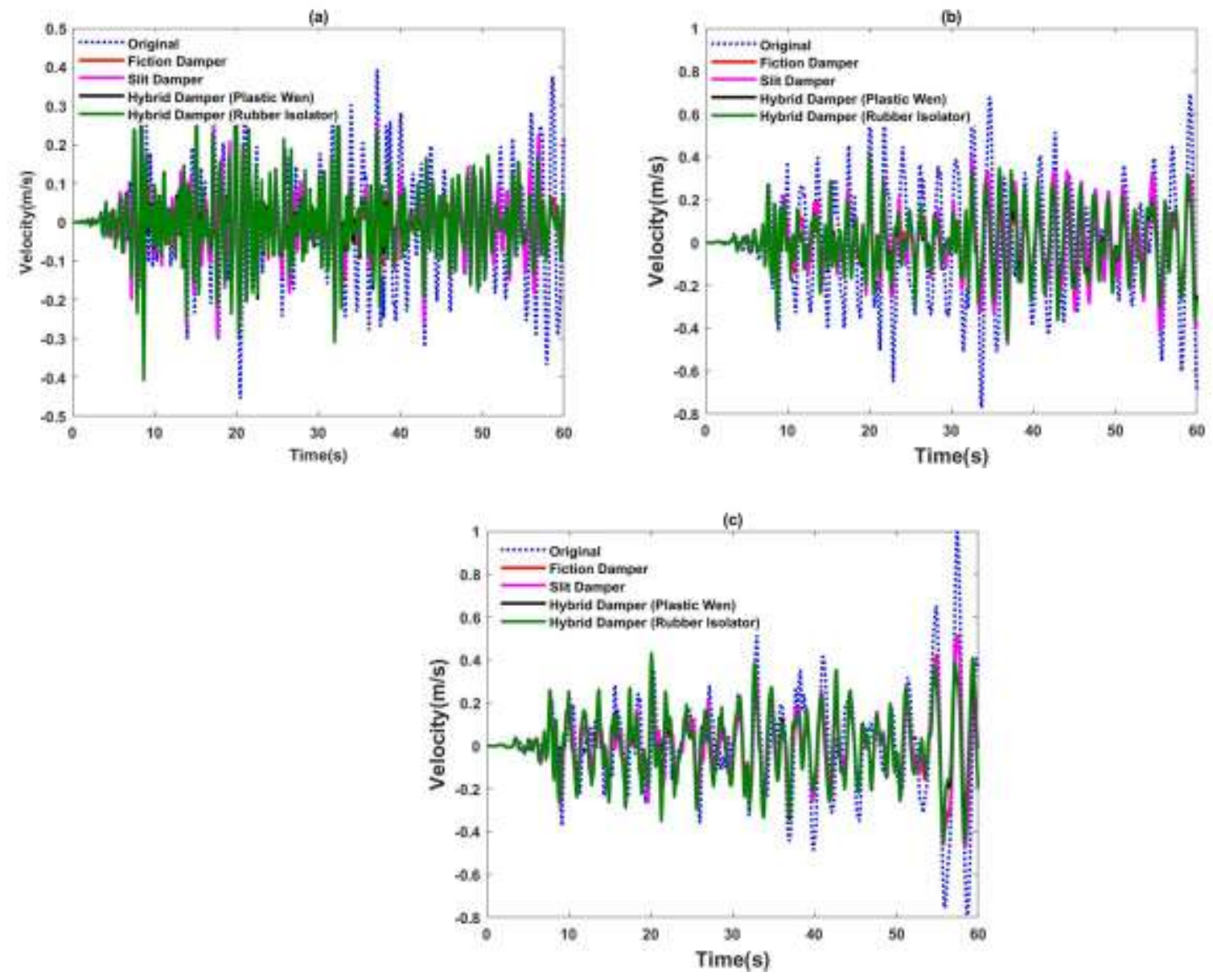

Figure 6. Velocity of the structure: (a) the 5-story structure; (b) the 10-story structure; (c) the 15-story structure
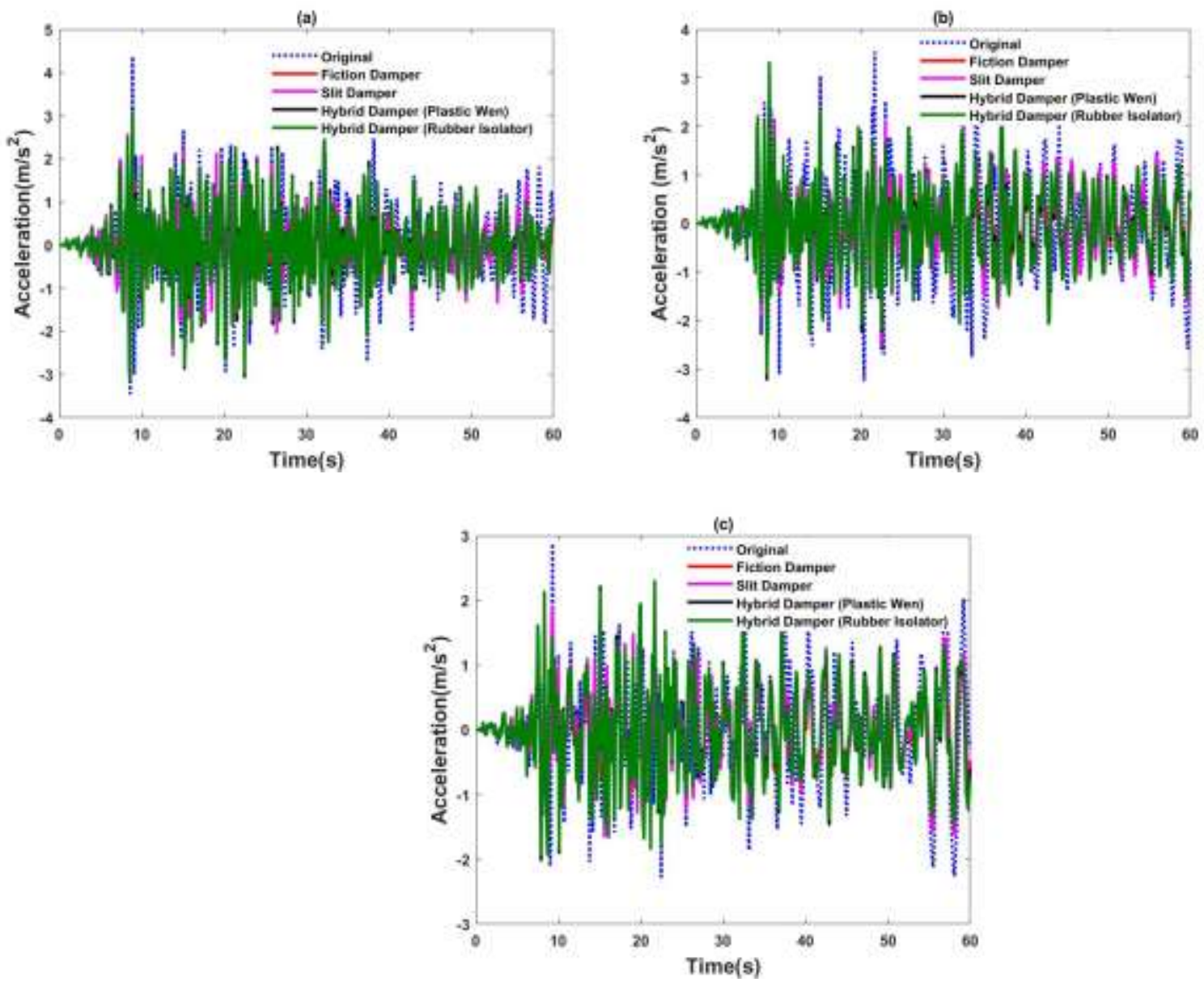
International Journal of Advances in Scientific Research and Engineering (ijasre), Vol 5 (5), May-2019

Fig 7. Acceleration of the structure: (a) the 5-story structure; (b) the 10-story structure; (c) the 15-story structure
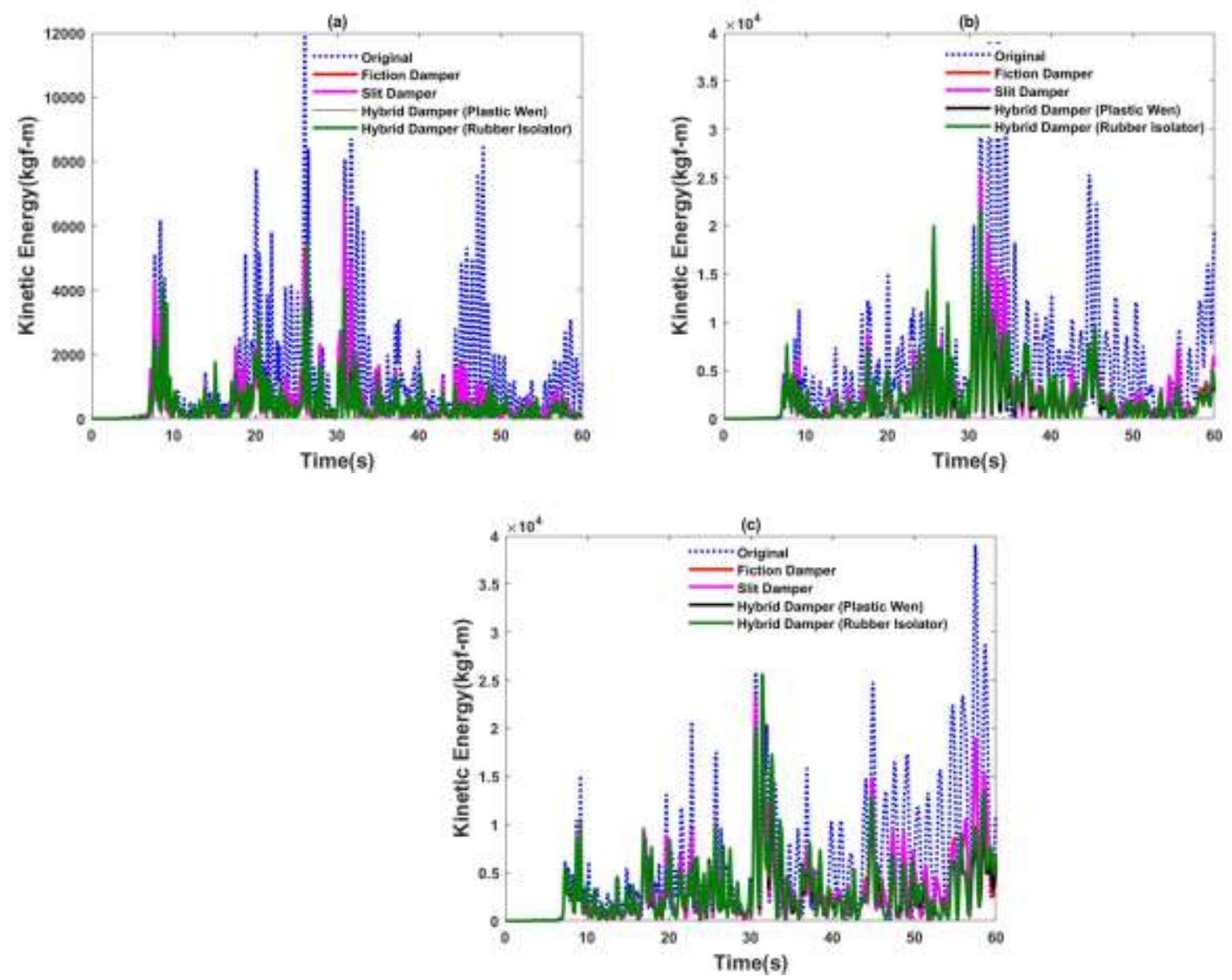

Figure 8. Kinetic energy of the structure: (a) the 5-story structure; (b) the 10-story structure; (c) the 15-story structure

\section{CONCLUSION AND DISCUSSION}

According to the obtained results, the seismic performance of the structures equipped with damper was better than structures without dampers, so that by placing these dampers in structures according to the pushover analysis, drift and the maximum displacement of the roof were decreased by $33 \%$ and $23 \%$, respectively. According to the time history analysis, the displacement of structures by $\% 60$, the velocity of structures also by $\% 70$, the acceleration of structures by $45 \%$ and the kinetic energy of the structures by \% 51 compared to the original structures. Of course, structures with dampers with Rubber Isolator behavior due to their existence, the effective damping coefficient has a better performance than the dampers modeled with Plastic Wen behavior.

\section{REFERENCES}

[1]. C. Xia, R.D. Hanson, "Influence of ADAS element parameters on building seismic Response.", Journal of Struct Eng ASCE, 118(7),1992, pp.1903-1918.

[2] . J. Park, J. Lee and J. kim, "Cyclic test of buckling restrained braces composed of square steel rods and steel tube.", Journal of Steel Compos Struct, 13, 2012, pp.423- 436.

[3] . R.W.K. Chan, F. Albermani," Experimental study of slit damper for passive energy Dissipation.", Journal of Eng Struct, 30(4), 2008, pp.1058-1066.

[4]. S.H. Oh, Y.J, Kim, H.S. Ryu, "Seismic performance of steel structures with slit Dampers.", Journal of Eng Struct, 31(9), 2009, pp.1997-2008.

[5]. H. Saffaria, A.A. Hedayatb, M. Poorsadeghi Nejad, "Post-Northridge connections with slit dampers to enhance strength and ductility dampers to enhance strength and ductility dampers to enhance strength and ductility.", Jornal of Constr Steel Res, 80(1), 2013, pp.138-152. 
International Journal of Advances in Scientific Research and Engineering (ijasre), Vol 5 (5), May-2019

[6] . J. Seo, Y. Kim, J. Hu, "Pilot study for investigating the cyclic behavior of slit damper systems with recentering shape memory alloy (SMA) bending bars used for seismic restrainers.", Journal of Appl Sci, 5, 2015, pp.187-208.

[7]. C.H. Lee, S.H. Lho, D.H. Kim, J. Oh and Y.K. Ju, "Hourglass-shaped strip damper subjected to monotonic and cyclic loadings.", Journal of Eng Struct, 119(15), 2019, pp.122-134.

[8]. C.H. Lee, Y.K. Ju, J.K. Min, S.H. Lho and S.D Kim, “Non-uniform steel strip dampers subjected to cyclic loadings.", Journal of Eng Struct, 99(15),2015, pp.192-204.

[9]. A. Pall and R. Pall, "Performance based design using pall friction dampers - an economical design solution.", In: Proceedings, thirteenth world conference on earthquake engineering, Vancouver, 2004.

[10]. I.H. Mualla and B. Belev, "Performance of steel frames with a new friction damper device under earthquake excitation.", Journal of Eng Struct, 24(3), 2004, pp.365-371.

[11] . C.H. Lee, J. Ryu, J. Oh, C.H. Yoo and Y.K. Ju, "Friction between a new low-steel composite material and milled steel for SAFE Dampers.", Journal of Eng Struct, 122, 2016, pp.279-295.

[12]. C.S Tsai, K.C. Chen, and C.S. Chen, "Seismic resistibility of high-rise buildings with combined velocity-dependent and velocity-independent devices.", In: 1998 ASME pressure vessels and piping conference; vol. 366. San Diego, CA, ASME, Fairfield (NJ), 1998, pp.103-110.

[13]. C.S. Chen, K.C. Chen, W.S. Pong, and C.S. Tsai, "Parametric study for buildings with combined displacement-dependent and velocity-dependent energy dissipation devices.", Journal of Struct Eng Mech, 14(1), 2002, pp.85-98.

[14]. K. Uetani, M. Tsuji, and I. Takewaki, "Application of optimum design method to practical building frames with viscous dampers and hysteretic dampers.", Journal of Eng Struct, 25, 2003 pp.579-592.

[15]. J. Marko, D. Thambiratnam, and N. Perera, "Influence of damping systems on building structures subject to seismic effects.", Journal of Eng Struct, 26(13), 2004, 1939-1956.

[16]. J.D. Marshall, and F.A. charnery, "Seismic response of steel frame structures with hybrid passive control systems." Journal of Earthquake Eng Struct Dynam ,41(4), 2012, pp.715-733.

[17]. Y. Murakami, K. Noshi, K. Fujita, and M. Tsuji, "Takewaki, I. Simultaneous optimal damper placement using oil, hysteretic and inertial mass dampers.”. Journal of Earthquakes Struct, 5(3), 2013, pp.261-276.

[18]. J. Lee and J. Kim, "Seismic performance evaluation of moment frames with slitfriction hybrid dampers.", Journal of Earthquakes Struct, 9(6), 2015, pp.1291-1311.

[19]. C.H. Lee, J. Kim, D.H. Kim, J. Ryu, Y.K. Ju, "Numerical and experimental analysis of combined behavior of shear-type friction damper and non-uniform strip damper for multi-level seismic protection.”, Journal of Eng Struct, 114(1), 2016, pp.75-92.

[20]. J. Lee, H. Kang and J. Kim, "Seismic performance of steel plate slit-friction hybrid dampers.", Journal of Egn Struct, 136, 2016, pp.128-139.

[21]. ETABS, "Integrated Building Design Software."Version16, Computer and Structures In, 2016.

[22]. ASCE07, American society of civil engineers. Seismic evaluation and retrofit of existing building, 2016.

[23]. FEMA P695, "Quantification of Building Seismic Performance Factors.", Federal

Emergency Management Agency Washington, 2009.

[24]. M. Bhandari, S.D. Bharti, M.K. Shrimali, and T.K. Datta, "Assessment of proposed lateral load patterns in pushover analysis for base-isolated frames.", Engineering Structures, 175, 2018, pp.531-548.

[25]. M. Shokrabadi, M. Banazadeh, M. Shokrabadi, and A. Mellati, “Assessment of seismic risks in code conforming reinforced concrete frames.", Engineering Structures , 98, 2015, pp.14-28. 